\title{
DAMPAK USAHA KEGIATAN PENAMBANGAN PASIR TERHADAP PERUBAHAN MATA PENCAHARIAN DI KABUPATEN MUNA BARAT
}

\author{
Irfan Ido ${ }^{1}$ \\ 'Dosen Fakultas Kebumian dan Teknik Pertambangan Universitas Halu Oleo \\ irfan.ido@uho.ac.id
}

\begin{abstract}
Tondasi Village is one of the Villages in the North Tiworo Sub-District West Muna District as a producer of sand extraction. This study aims to find out: (1) Sand mining business in Tondasi Village, North Tiworo District, West Muna Regency; (2) Determine what factors cause people to change their livelihood patterns. The sample in this study used the Non Probability Sampling technique that was chosen which was saturated sampling (census). In this study the samples taken were 229 Tondasi villagers. Data were analyzed with 3 stages, namely data reduction, data presentation and conclusion. The results of this study show that sand mining in Tondasi Village initially used traditional tools, but the technological development is increasingly rapid, so sand mining in Tondasi Village uses a sand suction machine. There are 3 factors that cause the community to change their livelihood to become sand miners, namely the income factor, the lack of catches for the people who are fishermen background, and the failure of the crop due to uncertain seasonal factors for the people who are farmers. However, there are 3 factors that have caused the community to leave their livelihood as sand miners, namely the emergence of new technology to mine the sand which makes traditional sand miners unable to compete with miners who use vacuum cleaners, the absence of mining permits from the government and the emergence of awareness about the importance of protecting the environment.
\end{abstract}

Keywords: Sand Mining Business, Livelihood Changes

\section{LATAR BELAKANG}

Indonesia adalah negara di Asia Tenggara yang dilintasi garis khatulistiwa dan berada di antara benua Asia dan Australia serta antara Samudra Pasifik dan Samudra Hindia. Indonesia adalah negara kepulauan terbesar di dunia yang terdiri dari 13.466 pulau. Nama alternatif yang biasa dipakai adalah Nusantara. Sumber daya alam Indonesia berupa minyak bumi, timah, gas alam, nikel, kayu, bauksit, tanah subur, batu bara, emas, dan perak dengan pembagian lahan terdiri dari tanah pertanian. Negara Indonesia ini adalah Negara yang sangat kaya akan sumber daya alamnya. Potensi sumber daya alam yang dimiliki Indonsia sendiri, merupakan kekayaan yang dimiliki oleh seluruh masyarakat Indonesia dan harus dimanfaatkan secara maksimal untuk kepentingan rakyat Indonesia. Sumber daya alam adalah segala sesuatu yang muncul secara alami yang dapat digunakan untuk pemenuhan kebutuhan manusia pada umumnya.

Seluruh kekayaan yang ada di atas maupun di dalam perut bumi Indonesia diperuntukan kepada kesajraan rakyat Indonesia. Undang-undang Dasar 1945 pasal 33 ayat 3 menyatakan bahwa bumi, air, dan segala kekayaan yang terkandung didalamnya dikuasai oleh negara dan dipergunakan sebesar-besarnya bagi kemakmuran rakyat. Undang-undang tersebut memberikan dasar dan penegasan dengan jelas, bahwa rakyat Indonesia mendapat jaminan konstitusional untuk memanfaatkan kekayaan bumi Indonesia. Banyaknya sumber daya alam yang ada di Indonesia mendorong masyarakat Indonesia untuk merubah pola mata 
Vol 1. No.1, April 2019: pp. 30-37.Copyright@2019 PUBLICUHO Faculty of Social and Political Sciences Halu Oleo University, Kendari, Southeast Sulawesi, Indonesia. e-ISSN: 2621-1351. Open Access at:

http://ojs.uho.ac.id/index.php/PUBLICUHO

Jounal publiuho is licensed under a Creative Commons Attribution 4.0 International License, which permits
unrestricted use, distribution, and reproduction in any medium, provided the original work is properly cited.

pencaharian mereka. Menjelaskan bahwa mata pencaharian adalah keseluruhan kegiatan untuk mengeksploitasi dan memanfaatkan sumber-sumber daya yang ada pada lingkungan fisik, sosial dan budaya yang terwujud sebagai kegiatan produksi, distribusi dan konsumsi. Dengan kata lain sistem mata pencaharian adalah cara yang dilakukan oleh sekelompok orang sebagai kegiatan sehari-hari guna usaha pemenuhan kehidupan, dan menjadi pokok penghidupan baginya.

Manusia untuk memperoleh taraf hidup yang layak dalam keadaan alam yang tidak menentu seperti sekarang ini, maka ada sebagian masyarakat beralih mata pencaharian dengan memanfaatkan sumber daya alam yang ada dengan maksud dapat meningkatkan taraf perekonomian kearah yang lebih baik sebagaimana dilakukan oleh sebagian masyarakat di Kabupaten Muna Barat.

Kabupaten Muna Barat merupakan salah satu Kabupaten hasil pemekaran dari Kabupaten Muna yang diresmikan pada tahun 2014 dengan Ibu Kota Laworo. Luas daerah Kabupaten Muna Barat yaitu 1.022,89 km². Salah satu Desa yang sebagian masyarakatnya merubah pola mata pencahariannya yaitu Desa Tondasi. Desa Tondasi berjarak 30,20 km dari pusat Kota Muna Barat. Masyarakat Desa Tondasi beradaptasi dengan lingkungan dan memanfaatkan sumber daya alam di sekitarnya dengan maksud untuk bisa memenuhi dan menopang kehidupannya. Satu-satunya Desa di Kecamatan Tiworo Utara sebagai penghasil pasir yaitu Desa Tondasi. Masyarakat Desa Tondasi mayoritas mata pencahariannya yaitu di sektor agraris tetapi dengan adanya usaha penambangan pasir, maka ada sebagian masyarakat yang merubah pola mata pencahariannya menjadi penambang pasir.

\section{METODE PENELITIAN}

Penelitian ini dilakukan di Desa Tondasi Kecamatan Tiworo Utara Kabupaten Muna Barat .

Adapun tahapan yang dilakukan dalam penelitian ini, meliputi:

a) Observasi: Pada tahap observasi lapangan diperoleh gambaran nyata mengenai aktivias penambangan dan perubahan kondisi lingkungan fisik maupun sosial yang terjadi di lokasi penambangan pasir di pesisir pantai.

b) Wawancara: Pada tahap wawancara diperoleh informasi mengenai kondisi yang sebenarnya melalui wawancara langsung dengan responden menggunakan pedoman kuesioner.

c) Dokumentasi: Pada tahap dokumentasi diperoleh gambaran lokasi penelitian yang dijadikan sebagai data pendukung. Teknik penentuan sampel dalam penelitian ini dilakukan dengan menggunakan teknik Non Probability Sampling yang dipilih yaitu dengan sampling jenuh ( sensus ). Metode sampel jenuh ( sensus ) adalah teknik penentuan sampel bila semua anggota populasi digunakan menjadi sampel. Dalam penelitian ini sampel yang diambil adalah seluruh masyarakat Desa Tondasi yaitu sebanyak 229 Kepala Keluarga

d) Analisis dan Pengolahan Data, yang digunakan dalam penelitian ini adalah :

1. Reduksi Data: Peneliti melakukan reduksi data ( Data Reduction) terhadap data-data yang telah dikumpulkan. Reduksi data merupakan proses pemilihan, pemusatan perhatian, pengabstaksian dan pentransformasian data kasar dari lapangan. Peneliti membagi data kedalam beberapa kategori agar data-data menjadi terpusat dan terpilah dengan baik yaitu data-data mengenai usaha kegiatan pasir yang dilakukan oleh masyarakat Desa Tondasi dan alasan atau faktor-faktor yang menyebabkan masyarakat merupah pola mata pencaharian mereka.

2. Penyajian Data: Data-data yang telah direduksi kemudian disajikan (Data Display). Penyajian data dalam penelitian seringkali dalam bentuk narasi teks. Teknik analisis ini kemudian oleh peneliti disajikan dengan data-data yang telah tereduksi kedalam bentuk narasi. Peneliti menarasikan atau 
mendeskripsikan tentang usaha kegiatan penambangan pasir di Desa Tondasi serta menarasikan tentang alasan atau faktor-faktor apa saja yang menyebabkan masyarakat Desa Tondasi merubah pola mata pencahariannya.

3. Penarikan Kesimpulan: Penariakan kesimpulan (conclusion drawing or verification) merupakan aktivitas akhir yang dilakukan peneliti. Peneliti menarik sebuah kesimpulan dari data yang telah direduksi dan disajikan. Penarikan kesimpulan ini adalah penting karena merupakan jawaban terhadap persoalan atau masalah penelitian ini yaitu tentang bagaimana gambaran usaha penambangan pasir di Desa Tondasi serta alasan atau faktor-faktor yang menyebabkan perubahan mata pencaharian masyarakat Desa Tondasi.

\section{HASIL DAN PEMBAHASAN}

\section{Gambaran Umum Usaha Penambangan Pasir Desa Tondasi Kecamatan Tiworo}

Usaha pertambangan pasir mulai ada di Desa Tondasi sekitar \pm 10 tahun yang lalu. Pertama kali sebelum menggunakan mesin penyedot dalam penambangan ini masyarakat Desa Tondasi mengambil pasir dengan menggunakan alat-alat yang sangat sederhana yaitu berupa karung sebagai tempat untuk menyimpan pasir untuk dibawa di tempat penampungan dengan menggunakan perahu yang telah disiapkan. Usaha penambangan pasir dengan cara tradisional ini hanya bisa dilakukan pada saat air laut surut. Kemudian dengan perkembangan zaman dan semakin majunya teknologi yang ada mulai terpikirkan oleh masyarakat Desa Tondasi Penambangan yang awalnya hanya dengan menggunakan alat-alat yang sederhana kini telah berganti dengan menggunakan mesin penyedot pasir. Penambangan dengan menggunakan mesin pertama kali dimulai pada sekitar \pm 3 tahun yang lalu tepatnya pada tahun 2015. Usaha pertambangan pasir di Desa Tondasi ini dilakukan karena kekayaan sumber bahan galian $\mathrm{C}$ berupa pasir sangat prospek dan potensial mengingat keadaan alam di Kecamatan Tiworo Utara adalah banyak pulau-pulau kecil yang banyak akan bahan tambang pasir dan sungai-sungai serta lokasi lahan yang berawa. Lahan untuk pengambilan pasir di Desa Tondasi adalah milik umum siapapun boleh mengambil pasir.

Beberapa tahapan yang dilakukan dalam usaha penambangan pasir diantaranya adalah :

\section{A. Tahap Persiapan.}

Tahap persiapan biasanya didahului dengan kegiatan pengangkutan berbagai jenis peralatan yang digunakan pada saat melakukan penambangan. Alat yang digunakan yaitu perahu, bahan bakar, mesin penyedot pasir, pompa air serta pipa.
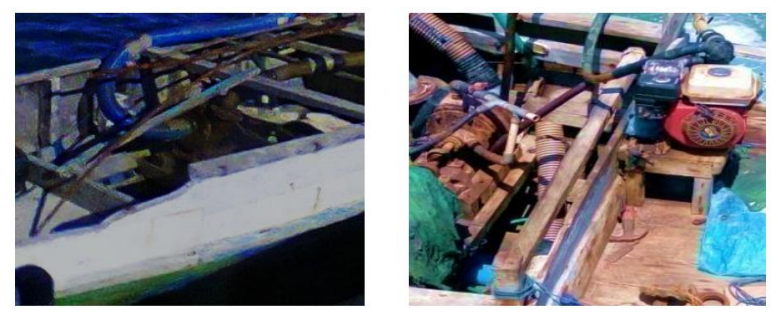

\section{Gambar 2. Mesin penyedot pasir dan mesin pompa air}

Perahu berfungsi sebagai alat untuk mengangkut peralatan untuk melakukan penambangan, kendaraan bagi penambang serta tempat untuk menampung pasir hasil penyedotan. Mesin penyedot pasir sebagai alat untuk mengangkat pasir yang berada di dasar laut atau dasar sungai. Pompa air/penyedot air sebagai alat untuk memompa air, air yang dipompa yaitu air yang mengendap diperahu tempat penampungan pasir agar beban 
Vol 1. No.1, April 2019: pp. 30-37.Copyright@2019 PUBLICUHO Faculty of Social and Political Sciences Halu Oleo University, Kendari, Southeast Sulawesi, Indonesia. e-ISSN: 2621-1351. Open Access at:

http://ojs.uho.ac.id/index.php/PUBLICUHO

Jounal publiuho is licensed under a Creative Commons Attribution 4.0 International License, which permits
unrestricted use, distribution, and reproduction in any medium, provided the original work is properly cited.

perahu sedikit berkurang. Pipa berfungsi sebagai tempat atau media tempat lewat pasir yang disedot di dasar sungai atau laut. Bahan bakar berfungsi sebagai bahan untuk menjalankan mesin perahu, mesin pompa air serta mesin penyedot pasir. Bahan bakar dapat diperoleh dari pertamina yang berada di pinggir pantai Desa Tondasi. Dalam hal pengangkutan peralatan tambang yang perlu diperhatikan adalah jalan yang akan dilalui. Hal ini perlu diperhitungkan secara matang agar tidak terjadi pemborosan bahan bakar. Pada tahap ini dilakukan pengamatan, dimana saja biasanya pasir akan terkumpul banyak, maka setelah diketahui lokasinya, maka masyarakat akan langsung melakukan penyedotan pasir.

\section{B. Tahap Eksploitasi/Penyedotan Pasir}

Kegiatan yang dilakukan pada tahap ini utamanya berupa penambangan atau penyedotan pasir. Bahan tambang yang terdapat di daerah perbukitan, walaupun jenisnya sama, misalnya pasir, teknik penambangannya akan berbeda dengan deposit pasir yang terdapat di daerah pedataran, apalagi yang terdapat di dalam alur sungai maupun laut. Penyedotan pasir biasanya dilakukan dengan alat penyedot pasir. Awalnya masyarakat Desa Tondasi melakukan penambangan pasir dengan cara tradisional yaitu dengan menggali pasir dengan alat-alat sederhana seperti cangkul dan sekop kemudian dimasukan kedalam karung. Karung berisi pasir diangkut di kapal untuk disimpan di tempat penampungan pasir. Menambang pasir dengan cara tradisional ini cukup menguras banyak tenaga dalam melakukan penambangan, namun setelah adanya mesin penyedot pasir masyarakat tidak menambang lagi secara tradisional karena menambang pasir dengan menggunakan alat penyedot pasir sangat mudah dilakukan dan tidak menguras banyak tenaga.

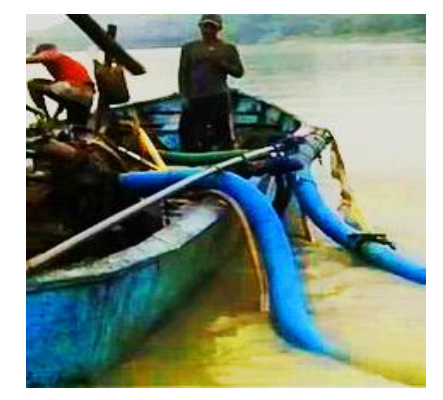

Gambar 3. Kegiatan penyedotan pasir

Cara penambangan pasir dengan alat penyedot ini yaitu cukup dengan menurunkan pipa penyedot ke dasar laut atau sungai. Pasir yang naik dari hasil penyedotan masuk kedalam mesin untuk memisahkan material pasir dengan material selain pasir. Material pasir akan masuk kedalam perahu penampung pasir melalui pipa sedangkan material selain pasir akan dibuang ke laut. Pasir yang masuk ke perahu penampung masih bercampur dengan air, air tersebut disedot menggunakan mesin penyedot air untuk dibuang agar beban perahu sedikit terkurangi. Namun ada sedikit kelemahan dalam menggunakan mesin penyedot pasir ini yaitu ketika mesin penyedot menggalami penyumbatan dan menyebabkan pasir tidak bisa tersedot, sehingga harus menyelam ke dasar laut untuk membuka material-material yang menyebabkan penyumbatan.

Usaha penambangan pasir di Desa Tondasi dilakukan di daerah aliran sungai dan di laut. Untuk penambangan pasir halus dilakukan di daerah aliran sungai sedangkan untuk pasir kasar dilakukan di laut atau pantai. Penambangan pasir dengan metode penyedotan ini lebih bagus dibandingkan dengan cara tradisional karena cara penyedotan dapat menghasilkan pasir yang tidak bercampur dengan material lain seperti tanah/lumpur, akar kayu, keong maupun batu-batu kecil. 


\section{Pengangkutan}

Pada tahap ini pasir yang telah disedot dengan mesin penyedot di tampung dalam perahu penampung pasir untuk dibawa di tempat penampungan pasir. Dalam melakukan tahapan pengangkutan pasir yang perlu diperhatikan adalah keadaan pasang dan surut air laut. Jika muatan kapal berisi pasir cukup banyak maka pengangkutannya dilakukan pada saat air laut pasang sedangkan jika pada saat surut tetap dibolehkan mengangkut pasir namun beban kapal dikurangi karena kapal pengangkut pasir tidak mampu mencapai tempat penampungan pasir karena baling-baling kapal dapat menyentuh dasar laut dan dapat mengakibatkan kerusakan pada baling-baling kapal pengangkut pasir. Pasir yang diperoleh dari tempat penyedotan pasir akan diangkut dan ditampung ditempat penampungan pasir.

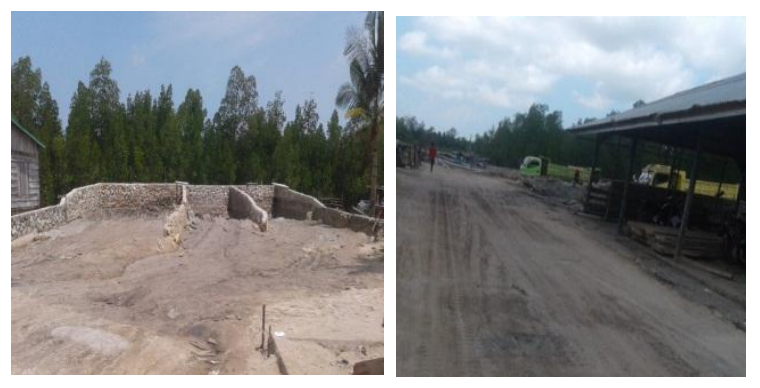

Gambar 6. Tempat penampungan pasir

Volume produksi pasir per perahunya berbeda - beda untuk setiap responden ada yang volume produksinya sebesar 7 ret ada juga 4 ret tergantung ukuran kapal yang dimiliki oleh responden. Dalam sehari bisa melakukan penyedotan sebanyak 2 kali. Saluran pemasaran pasir yaitu masyarakat yang membutuhkan pasir langsung datang ke tempat penampungan untuk membeli pasir.

\section{Faktor-Faktor yang Menyebabkan Masyarakat Merubah Mata Pencaharian Menjadi Penambang/Buruh} Pasir.

Adapun faktor-faktor yang menyebabkan masyarakat menjadi penambang dan buruh pasir yaitu sebagai berikut :

\section{A. Faktor Internal}

Faktor-faktor yang muncul karena terjadinya dinamika kehidupan dalam masyarakat yang bersangkutan tanpa ada pengaruh dari luar, yaitu diantaranya :

\section{Faktor Ekonomi}

Tekanan ekonomi kebutuhan akan sandang pangan dan papan tentu saja merupakan kebutuhan yang tidak dapat dihindari, selain itu kebutuhan akan hiburan, komunikasi dan pendidikan juga mendesak untuk dipenuhi. Dengan hanya mengandalkan pendapatan mereka sebagai petani, nelayan tentu saja tidak akan mencukupi kebutuhan tersebut. Pendapatan Nelayan masyarakat Desa Tondasi dalam per hari yaitu berkisar 100.000 sampai 150.000 ribu rupiah. Dalam sebulan mereka para Nelayan hanya bisa melaut 2 minggu karena kondisi arus yang kuat. Jadi, penghasilan mereka dalam sebulan yaitu berkisar 1.400 .000 sampai 2.100 .000 ribu rupiah. Untuk pendapatan pekerja sebagai petani yaitu berkisar antara 1.500 .000 sampai 2.000 .000 rupiah per bulan. Kebutuhan ekonomi yang semakin meningkat membuat mereka mengambil keputusan untuk menjadi penambang/buruh pasir diharapkan akan memulihkan keadaan ekonomi keluarga. 
Vol 1. No.1, April 2019: pp. 30-37.Copyright@2019 PUBLICUHO Faculty of Social and Political Sciences Halu Oleo University, Kendari, Southeast Sulawesi, Indonesia. e-ISSN: 2621-1351. Open Access at:

http://ojs.uho.ac.id/index.php/PUBLICUHO

Jounal publiuho is licensed under a Creative Commons Attribution 4.0 International License, which permits unrestricted use, distribution, and reproduction in any medium, provided the original work is properly cited.

\section{B. Faktor Eksternal}

\section{Kurangnya Hasil Tangkapan Bagi Nelayan}

Nelayan dengan ikatan ekonomi maupun historisnya telah memanfaatkan sumber daya hayati laut ini secara turun temurun. Namun kondisi saat ini menunjukkan bahwa berada di tengah melimpahnya kekayaan sumber daya alam hayati laut dan pesisir ternyata belum dapat membuat perekonomian nelayan Indonesia terangkat dari garis kemiskinan.

Keterpurukan nelayan ini diperparah oleh kerusakan ekologi yang terjadi pada ekosistem pesisir dan laut yang menjadi sumber mata pencahariannya.Salah satu faktor penyebab terjadinya perubahan ekologi pesisir dan laut ini adalah perubahan iklim. Perubahan iklim mengacu pada perubahan-perubahan yang terjadi pada iklim dari waktu ke waktu baik secara alamiah maupun disebabkan oleh aktivitas manusia. Dampak yang ditimbulkan oleh perubahan iklim yaitu terjadinya kenaikan muka air laut. Pendapatan Nelayan sebelum terjadi perubahan iklim yang tidak menentu yaitu berkisar antara 3.500.000 sampai dengan 4.200.000. Namun karena iklim yang tidak menentu penghasilan mereka menjadi menurun berkisar 1.400 .000 sampai dengan 2.100.000 ribu rupiah. Masalah iklim ini menyebabkan Nelayan di Desa tondasi hasil tangkapannya berkurang sehingga ada sebagian nelayan beralih mata pencaharian menjadi penambang/buruh pasir

\section{Iklim yang Tidak Menentu Membuat Petani Gagal Panen}

Perubahan iklim, menjadi satu ancaman yang sangat serius terhadap sektor pertanian, yang mendatangkan masalah baru bagi keberlanjutan produksi pangan dan sistem produksi pertanian. Iklim yang tak menentu tersebut, mengakibatkan petani sulit untuk bercocok tanam. Kini telah berdampak pada kebanyakan petani di Desa Tondasi yang mengeluhkan kondisi cuaca, yang sesekali dapat berubah dengan cepat. Tak jarang, gagal panen pun datang menghampiri para petani. Dampak lain, cuaca yang tak menentu itu mengakibatkan timbulnya berbagai macam hama pengganggu tanaman pertanian. Dengan keadaan iklim yang tidak menentu seperti sekarang ini maka sebagian para petani di Desa Tondasi memilih menjadi penambang/buruh pasir.

C. Faktor-Faktor yang Menyebabkan Masyarakat Meninggalkan Mata Pencaharian Penambang/Buruh Pasir. Adapun faktor-faktor yang menyebabkan sebagian masyarakat di Desa Tondasi meninggalkan pekerjaan sebagai penambang pasir yaitu sebagai berikut :

\section{Munculnya Teknologi Baru untuk Menambang Pasir}

Teknologi adalah bentuk kreasi dari manusia yang diwujudkan dengan alat, dan teknik tertentu sehingga dapat mempermudah suatu pekerjaan dalam menghasilkan sesuatu. Semakin majunya ilmu pengetahuan dan teknologi membuat manusia mengerjakan pekerjaan dalam kehidupan sehari-hari menjadi sangat mudah dan cepat. Pada dasarnya, teknologi diciptakan untuk membantu atau memudahkan pekerjaan manusia. Namun, kemajuan teknologi tersebut mempunyai kelebihan dan kekurangan para penggunanya. Adapun kelebihan dari adanya teknologi, yaitu dapat memudahkan manusia dalam menyelesaikan pekerjaannya sehari-hari. Selain itu, lebih memudahkan dalam mendapatkan komunikasi atau informasi. Dengan adanya kemajuan teknologi, maka hal yang tidak mungkin tersebut dapat menjadi mungkin untuk dilakukan.

Munculnya suatu alat untuk menambang pasir memang dapat mempermudah masyarakat dalam mengeksploitasi pasir secara besar-besaran namun sisi negatifnya akan mengakibatkan kerusakan pada lingkungan perairan dan pantai. Alat penyedot pasir yang digunakan oleh masyarakat di Desa Tondasi dalam menambang pasir terbilang cukup mahal sehingga hanya sebagian masyarakat yang dapat memperoleh alat tersebut. Karena hal tersebut membuat masyarakat yang menambang secara tradisional tergeser mata pencahariannya dan meninggalkan mata pecaharian mereka sebagai penambang pasir. 


\section{Tidak Ada Izin dari Pemerintah.}

Menurut Pasal 33 ayat 3 Undang-Undang Dasar 1945 menyebutkan bahwa bumi, air dan kekayaan alam yang terkandung di dalamnya di kuasai oleh Negara dan dipergunakan untuk sebesar-besarnya kemakmuran rakyat. Untuk tercapainya kesejahteraan dan kemakmuran rakyat Indonesia maka diselenggarakan berbagai macam kegiatan usaha dan produksi yang menunjang pembangunan. Salah satu kegiatan usaha yang menunjang pembangunan di Indonesia adalah sektor pertambangan.

Kabupaten Muna Barat khususnya Desa Tondasi adalah wilayah yang memiliki potensi tambang pasir yang cukup baik. Potensi yang ada memberikan peluang kepada masyarakat untuk menambang dan menjadi sumber mata pencaharian mereka. Namum pertambangan yang dilakukan masyarakat di Desa Tondasi ini tidak meiliki izin untuk melakukan usaha pertambangan. Dampak negatif yang disebabkan oleh kegiatan pertambangan tanpa izin ini dikhawtirkan dapat merusak lingkungan, pemborosan sumber daya mineral, kecelakaan tambang, juga merugikan negara khususnya pemerintah daerah, yang seharusnya menjadi salah satu pendapatan asli daerah (PAD).

Salah satu dampak yang disebabkan pertambangan tanpa izin yaitu mengakibatkan kerusakan lingkungan menjadi hal yang perlu diperhatikan oleh pelaku tambang. Karena belum adanya izin dari pemerintah maka sering sekali petugas menarik kapal-kapal penambang jika kedapatan menambang sehingga sebagian masyarakat yang awalnya penambang berhenti menjadi penambang karena takut mereka akan mengalami kerugian besar.

\section{Munculnya Kesadaran Tentang Pentingnya Menjaga Lingkungan.}

Penambangan pasir laut menyebabkan tingkat kekeruhan air laut sangat tinggi. Keruhnya air laut akan berdampak pada terumbu karang sebagai habitat pemijahan, peneluran, pembesaran anak, dan mencari makan bagi sejumlah besar organisme laut, terutama yang memiliki nilai ekonomis penting. jika terumbu karang tercemar, kematian biota laut di dalamnya pun akan tercemar. Hanya beberapa jenis biota yang bisa bertahan. Terumbu karang keberadaannya dipengaruhi kejernihan air, mudah rusak bahkan oleh aktivitas manusia yang menghasilkan endapan.

Penambangan pasir laut memicu berkurangnya hasil tangkapan ikan oleh nelayan. Hal ini disebabkan seluruh isi laut disedot tanpa pandang buluh. Tidak hanya pasir yang diangkat, tetapi telur-telur, anak ikan, terumbu karang, serta biota lainnya juga ikut musnah. Penambangan pasir laut memicu terjadinya abrasi dan hilangnya pulau-pulau kecil. Aktivitas ini melanggar Undang-Undang Nomor 1 Tahun 2014 (revisi atas Undang-Undang Nomor 27 Tahun 2007) tentang Pengelolaan Wilayah Pesisir dan Pulau-Pulau Kecil.

Kegiatan penambangan pasir pantai oleh masyarakat wilayah pesisir di Desa Tondasi masih terus berlangsung sampai saat ini dan terjadi di beberapa wilayah yang seharusnya menjadi area larangan penambangan pasir karena disamping telah terjadi kerusakan lingkungan namun di wilayah itu juga merupakan wilayah pantai wisata yang seharusnya dijaga dan dipelihara nilai keindahannya. Wilayah pantai yang dulu sering dikunjungi ketika hari libur namun kini telah rusak karena aktivitas penyedotan pasir. Jika penambangan ini terus berlanjut tanpa memperhatikan keadaan lingkungan sekitar akan mengakibatkan rusaknya pulau pulau kecil bahkan akan terancam tenggelam. Karena hal tersebut, sebagian masyarakat berhenti menjadi penambang dan mencari mata pencaharian lain. 


\section{KESIMPULAN}

Berdasarkan uraian hasil penelitian, maka dapat ditarik sebagai berikut:

1. Tahapan usaha penambangan pasir di Desa Tondasi yaitu meliputi tahapan persiapan alat yang digunakan dalam menambang, tahapan eksploitasi atau penyedotan pasir serta tahapan pengangkutan untuk ditampung di tempat penampungan pasir.

2. Faktor-faktor yang mempengaruhi terjadinya perubahan mata pencaharian masyarakat Desa Tondasi menjadi penambang/buruh pasir yaitu :

a) Tuntutan kebutuhan ekonomi keluarga, agar perekonomian masyarakat Desa Tondasi dapat meningkat dari pekerjaan sebelumnya.

b) Produktifitas tidak sesuai dengan yang diharabkan, yaitu hasil dari pekerjaan sebelumnya sebagai petani disebabkan terserang hama-hama yang baru karena iklim yang tidak menentu sehingga selalu gagal panen.

c) Kurangnya hasil tangkapan bagi masyarakat yng berlatar belakang sebagai Nelayan karena diakibatkan oleh perubahan iklim yang tidak menentu.

3. Faktor-faktor yang mempengaruhi masyarakat Desa Tondasi meninggalkan mata pencaharian sebagai penambang/buruh pasir yaitu :

a) Adanya teknologi dalam menambang pasir yaitu mesin penyedot pasir sehingga masyarakat yang menambang pasir dengan alat-alat manual tidak mampu bersaing.

b) Belum adanya izin resmi dari pemerintah dalam melakukan penambangan pasir sehingga masyarakat sering sekali dikejar-kejar oleh TNI Angkatan laut dan apabila meraka kedapatan menambang maka kapal mereka akan ditarik oleh petugas.

c) Munculnya kesadaran masyarakat tentang pentingnya menjaga lingkungan.

\section{REFERENSI:}

Fauzi, A., Ekonomi Sumber Daya Alam dan Lingkungan, Gramedia Pustaka Utama, Jakarta, 2004.

Kemong, B., 2017, Sistem Mata Pencaharian Hidup Nelayan Tradisional Sukubangsa Kamoro Di Desa Tipuka Kecamatan Mapurujaya Kabupaten Mimika Propinsi Papua, Jurnal

BPS, 2017., Kecamatan Tiworo Utara dalam Angka. 